\title{
XVII. Remarks on the transition rocks of Werner
}

\author{
Thomas Allan Esq. F.R.S. Edin.
}

To cite this article: Thomas Allan Esq. F.R.S. Edin. (1813) XVII. Remarks on the transition rocks of Werner, Philosophical Magazine Series 1, 42:184, 91-102, DOI: 10.1080/14786441308638292

To link to this article: http://dx.doi.org/10.1080/14786441308638292

曲 Published online: 27 Jul 2009.

Submit your article to this journal

Џ Article views: 2

Q View related articles ¿ 
thereby occasioned peculiar characteristics in the poetry of different nations. The more detactied, unmix:d, and steady that the society of any comnty preserves itself, the more original and singular will be the characteristics of its poetry; and by the sane rule, accorting to the intimacy and extent of intercourse which nations cultivate with one another, the more various and general will be the points of association in their habits of thinking, and their poetry consinuently approxinate to resemblance. The English nation more than any other that ever existed has cultivated a general intercourse with all parts of the globe; and accordingly we find perets in that coumiry nhose works, though comparatively popular there, are but little understood even by the learned of the continent. In the middle of the eighicuth century all Eurne was surprised by the appearance in that country of the poems of Ossian; works which, whatever mav be the debate as to their historical aubenticily, are admitted to be fine specinens of a kind of poctry culivated by the mountaineers of Scotland, and which was felt to be natural, and acknowledged to be original, even by those who questioned their antiquity. In like manner the conquests of the British in Indla have added to the stores of the British poets; and in Eugland a kind of poetry is tast growing into repule, which setens to bear the same sort of resemblance to that of the oriental poets which the productions of the muse in the days of Leo $X$. bore w that of the Greek and Roman poets of antiquity. $\mathrm{Mr}$. Southey has already brought this style to a high de. gree of excellence; and the specimens by SirWilliam Jones, along with the Transactions of the Asiatic Society, present to the world a glimpse of what pleasures may be added to our enjoyment of knowledge, by a nation which combines in its enterpuises the glory of victory and the advantages of commence; which carries in the rear of its armies the abundance of industry, and which, by its jurisprudence requiring the military to be subservient to the civil authorities. sends to the most dislatut regions the most enlightened of mankind in the capacity of advocates and judges.

[10 be continued]

XVII. Remarks on the Trausilion Rocks of Werner. By Thomas Allan, Esq. F.R.S. Edin.

[Concluded from p. 25.]

Granta countries usually present a bold and varied outline; but to this rule Cornivall is a most decided exception: 
its aspect is tame in the extreme, being comparatively flat,a circumatance visibly occasioned by the corroding operations of time. Nowhere are the vestiges of degradation so remarkable as here. The enormous deposites of tin in the different stream-works, of which that of Carnon is perhaps the most extensive, clearly prove the destruction of surrounding mountains. This tiv, in the shape of rounded pebhles, formed a stratum, of about a foot thick, under a ceposite of granite-gravel and mud, together forming an overburthen of forty feet thick, and occupying a valley of very areat extent. The lodes which furnished this tin mist have existed above the level of the deposite; and fion the quautity of metal deposited, they must have occupied a larere tract of country. Other nomuments of this gentral destruction may be found in the peaks which are seen in every direction in the granite disiricts of Cornwall. These are evidently the result of surrounding decomposition, and are formed of huge masses of rock, apparently piled on each other, with a regularity resembling masonry, and in all respects similar to the arrangement observable on the stummit of every mountain in Arran, where the traces of time are also deeply furrowed.

Roach Rock, a binary compound of quartz and hornblend, is anotber very remarkable instance of the same fact: this rock is flat at the fop, and being quite perpendicular on three sides, when viewed from the west, presents the appearance of a square castellated buildiug, which is rendered more conspicuous by being nearly of the same height as the tower of an adjoining church. There can be no doubt that this ongular rock owes its present appearance to the operations of time on the surrounding nraterials, which its peculiar composition has enabled it to withstand.

The killas likewise presents marks of degradation, where the eounty is composed of that rock. I noticed in some districts the roads mended entirely with quartz, (No. 24); the brilliant $w$ hite appearance of which, after a shower, had a very curious effect. I could not comprehend by what industry the accumulated heaps of this substance were obtained: at last I perceived that they were gathered from the aljoining fields, and in some places pictied from the surface of a common, by means of a hoe or maltock. That fragments of quartz should occur so unmixed with any others, is only to be accounied for by supposing that they formed the quartz veins in the killas, which, from superior tenacity, resisted decomposition, while the softer 
parts of the rock, yielding to the action of the weather, were reduced and carried awav.

We thus find, that the granige of Cornwall possesses the characters ascribed by Werner to that of the highest antiquity. Some inferences may likewise be drawn, in corroboration of its title to be clissed with rocks of this description, from the nature of the metallic veins by which it is traversed.

In the German account of the relative ages of metals, tin is the third, and wolfram the fourth in order of antiquity*. If veins containing these metals be considered in other countries as indicative of rocks of the oldest primitive formation, the same application must be made to those of Britain.

I may now ask, If this be not the oldest granile, where are we to find it? as it appears to me impossible that any substance can more decidedly concur with definition. In the Alps, Dr. Berger must have leant what primitive granite mrant; vet not a doubt escapes him, of the Cormish being any thing else. Distinctions either do or do not exist; if they do, character must be attended to ; if they do not, it is quite unnecessary to add the terms Sccondary and Tertiary to a substance possessing cvery attribute of a primary variety, merely because the structure of an adjoining rock does not accord with a specific theory.

Graunacke, or, as I shall in future call it, Killas, I have betore noticed, is a rock composed of fragmenis more or less comminuted, which must have existed in another state before they assumed their present arrangement. Along with the strata formed of these, beds of limestone are found, containing indications of nrganic remains. These are not confined solely to the limestone, they occur also in the killas; a fact. which may be witnessed at any time, either in the neighbourhood of Conistont, or on the right bank of the Blackwater, a litte below Fermoy, in the couniy of Cork, Nos. 66, 67.) The formation of this class of rocks was therefore subsequent to the formation of living animals, whose existence is supposed to be proved by the occurrence of organic remains in the composition of the rock.

In Cornwall, in Westmoreland, in Galloway, and in the.

* Jameson's Mineralogy, vol, iii. p. 275.

+ Since $I$ read this paper, I wrote to a friend at Coniston, requesting that a few of these specimens, well characterized, might be sent me: some of which are deposited, along with the rest, in the cabinet of the Scciety, 1Nis.64, 65.) 
counties of Down and Derry, this rock lies directly on granite, - a circumstance which we should at first sight bo inclined to consider as indicating its subsequent formation. This thought, however, vanishes the moment we contemplate the veins of granite by which it is traversed. Of these there are many examples; but the most striking are at the Louran in Gallow zy, and at St. Michael's Mount in Cornwall.

It is many years since Sir James Hall laid before this Society an account of his observations on the granite district of Galloway, of which the Louran forms a part; and to the persevering activity of that gentleman we are indebted for the display of one of the most interesting exhibitions of granite veins that exists. The peculiarities observable in Galloway were first pointed out to me by him ; and as he has so lately favoured the Society with a particular account of them, it leaves me nothing to say regarding that quarter.

At St. Michael's Mount, the shooting of the veins from the great mass of granite is also most strikingly exemplified. They were here first noticed by Professor Playfair, who compares them, most aptly, to the ramifications of the vegetable root*; for, indeed, nothing can be more illustrative of the phænomenon as it is here exhibited.

It is to be observed that granite veins, particularly when extremely minute, ustally differ in texture from the mass to which they belong. While the little peak of St. Michael's Mount maintains a similarity of character with all the rest of the Cornish granite, not only in point of internal structure, but with respect to the tin and copper veins which traverse it, as well as by the massive blocks, hewn by the corroding hand of time, which ornament its sumnit ; the veins that set off from it gradually become finer as they recede, but still preserve the perfect character of the rock.

The importance deservedly attached by Dr. Hutton to the phænomena of granite veins, gave rise to a variety of hypotheses among those who were inclined to consider this rock as the original deposite, who have accounted for their formation in different ways.

It was first stated, that they were formed of newer gras nite, and, if properly examined, would be found to cut the old granite as well as the rock which rested on it.

This opinion was once very strenurusly supported in this cosntry; but as facts would not bear it out, it was aban-

* Illustrations of the Huttonian Theory, p. 318. 
doned. I find, bowever, in a recent publication, something similar to it maintained by De Luc, who asserrs that the veins at St. Michael's Mount are not granite, but merely quartz, which traverses the granite as well as the stratified rock. I cannot comprehend how De Luc could have been so much deceived at this place; as simple inspection of the smallest specimen will prove that be was mistaken.

It was next said, that the veins in question were not true veins, but such as are termed Cotemporaneous. To support which, it was boldly asserted, that they never extended beyond the limits of such rocks as were composed of the same materials, gneiss and mica-slate.

I trust it is now distinclly shown, that they do extend beyond these limits, and likewise that they traverse rocks from which by no method of reasoning it can be supposed that they could possibly be formed by secretion.

The last opinion is that which has recently been brought forward by Dr. Berger*. After describing the granite veins of Si. Michael's Mount, he proceeds to say, that they are simply elevations on the plane of the granite existing previous to its being covered by the stratified rock; that the spaces between them were filler up as the grawwacke was deposited; and bence the abrasion of the surface brought to light a section which has merely an appearance of veins.

Were the devotion of Dr. Berger to his master less conspicuous in his genlogical disquisitions, I should be inelined, on the above statement, to call his character as an observer in question, having passed over in silence the detached masses of killas, which he could not fail to observe included in the granite, and which the above bypothesis is as far from accounting for as either of those mentioned before.

I have only a few specimens (Nos. $39,40,41$ ) to lay before the Society from the veins of St. Michael's Mount; but they are equally interesting and satisfactory. One exhibits a portion of the killas bounded on each side by granite; another, a portion of two granite veins traversing killas; and the third, a mass of killas included in the granite.

Simple inspection is sufficient, in the first place, to show that the opinion of $D_{e}$ Luc is groundless with respect to the substance of these veins. One of the specimens also contains two small veins of quartz, which are of the kind called Cotemporaneous; these keep the direction of the

- Trangactions of the Geological Society, vol, i. p. 147. 
seams of the stratified rock, and are cut off by the granite in the same line without any interraption.

To the opinion of Dr. Berger they also offer some reply. If the grauwacke had been deposited on the granite in the way he supposes, it is natural to conclude, that it would have been arranged in lines parallel to the sides of the elevations, somewhat similar to the coating of bark on the trunk of a tree : but in place of this, the seams of the killas are set at an angle of about $30^{\circ}$ to the plases of intersection with the granite; consequently, if deposited from a supernatant fluid, they have assumed a very different position from that which either mechanical or crystalline influence would have induced.

The hypothesis suggested to Dr. Hutton by the appearance of these veins, meets every difficulty: they conveyed to him evidence of being derived from a source of the greatest viole:ce; and also that nothing but liquid matter injected from below, conld have created the disturbancer amoug the stratified rocks, so conspicusus when in contact with granite. $A_{s}$ it is a self-evident position, that a rock which is cut by a true vein, must have existed in a solid state previous to the formation of that vein; so is it equally obvious, that if the vein can be traced into an adjoining mass, of which it is found to be a part, that mass must stand in the same relation, in point of period, to the rock which contains the vein, as the vein itself dnes: as also, that if pieces of one rock be found imbedded in anorber, the inclading rock must have been of subsequent forma: tion to the included. No theory, however, but that of Dr. Hutton can account for these appearances: to nothing but force can the position be attributed which the stratified rocks have assumed in the vicinity of the unstratified; and nothing but matter injecied in a liquid state, could possibly bave formed the shoots which traverse from the great mass of anite perforating the stratified rock, and at the same time envelop detached fragments of that rock. As the idea of violence in these operations has been so frequently combated, I cannot refrain from noticing here, a very striking mark of it I met with at Coul in Ross-shire, when visiting Sir George Mackenzie. There the strata of queiss are much disturbed by the invasion of granite veins; near which, on the outside curvatures of some of them $I$ perceived rents similar to what we might expect on bending a flattened mass of clay nearly deprived of moisture. I am formately enabled to present to the Society specimens. illustrative of this interesting fact (Nos. 68, 69.)

In: 
In the theory of Dr. Hutton, we find aiso some crounds to account for the diminution of gran in the substance of the veins. The same cause to which, in a former paper, [ attributed the gradation in the texture of greenstone, may be supposed to have acterl here. It does not, however, observe an equal constancy, some veins of granite being as coarse-grained as the mass to which they belong.

In a former part of this paper, I had occasion to notice an alteration which appears to take place in the texture of kilias, when in the vicinity of granite. This circumstance was so remarkable in Galloway, at the Louran and other places, that 1 took the strata so situated for mica-slate, although I had observed no line of separation between it and the killas. I was forcibly struck with this at the moment; but having then no time to follow it up, I was obliged to leave the country without any particular examination. It will be ohserved, by the specimens from St. Michael's Mount, that the killas there assumes the appearance of finegrained gueiss. At Wasseldale Crag, between Kendal and Shap, I noticed a rock, in the immediate vicinity of granite, quite similar; and I am told that the texture of the strata, near the granite of the mountains of Morne, is altogetber the same.

This alteration is always of a gradual nature; and is so imperceptible, that it affords a good example of what might be understood by the German term Passage, or transition from one species to another: this Passage, even admitting the substance altered, is of too limited a nature to constitute a distinct and totally different rock.

This alteration, if traced with attention, may lead to some very important results; but, without entering upon it at present, I shall content myself with recommending it to the notice of geologists, some of whom may consider it of too minute a nature to deserve attention. They may, however, rest assured, that it is only by an accurate examination, and a faithful detail of such objects, that we can hope to arrive ultimately at truth, the only solid basis of philosophic inquiry.

I may be accused of generalising too much in the foregoing statement, on grounds so limited : it must be remembered, however, that I have purposely confined myself to the examples of the relations which exist within my own knowledge, between the transition rocks and granite. The same phænomena are tamiliar, where gneiss and micaslate come in contact with that rock; but as these strata are considered to be of a very different age, the facts which

Vol. 42. No. 184. August 1813. G I might 
I might have cited, had my object been to prove the age of grmite wub respect to all other rocks, were unnecessary, when $m v$ purpose was to point ont the relative ages of killas and granite.

From what I have said, I consider mystf warranted in fnishing this paper with the following conclusions:

The Killas of Comwall belongs to the Transition serics of Werner.

The Granite of Cernwall is possessed of every character by which the Oldest varieties are distinguished.

That Granie, the nucleus round which Werner conceives all other rocks were deposited, is in some cases actually of a later date than the Tratsition series, which comprebends strata containing shells; and that its subsequent formation is clearly evinced by the appearances at St. Michacl's Mount.

Hence, that the distinction of Transition rocks is grounded on faise conclusions.

And finally, Thiat IVerner must make very material alterations on his present systemi, if he wishes to accommodate it to the phanomena so commonly presented in nature.

\section{APPENDIX.}

On a former occasion, I stated as my opinion, that all geological papers ought to be accompanied with specimens of the rocks of which they treated. This is a condition not always to be complied with, unless the intention to write precedes the examination, whon a collection may purposely be made; but when the idea suggests itself after one is far removed from the district, it amounts nearly to an impossibility. In the present instance, although $I$ be possessed of all the specimens necessary, they belong to a series which I formed for other purposes. Rather, however, than mutilate this, I have thought it better to present the whole to the Society, in whose possession I shall have an opportunity of referring to them at any time; and as they have signified their acceprance, it is necessary to add to $m y$ paper the following brief list of the minerals I collected, which are marked and numbered, as picked up on my route, commencing in Somersetshire, where the Transition rocks first made their appearance, and ending at Ilfracombe, after traversing Devon and Cornwall in different directions.

After leaving Bristol, on the road to Lxeter, we traverse the linuestone ridge of Mendip; to the south of which there is an exteusive plain, stretching to beyond Taunton, whose 
whose uniformity is occasionally interrunted by small isolaced hills, like islands in a lake. These are piobably formed of Transition rocks, ahibolit is on the plain itself, where the soil is lad open, which is principally composed of limestone delurs, horizontal strata of the same substance were exposed to view. Approaching Taunton, the road leads over some of these No. hills, and here it was that I met with strata bighly in1, 2. clined, very similar in colour and aspect to snme varieties of sandstone, but considerably more refractory under the hammer, indicating, I suspect, the commencement of the Transition series.

3. Vesicular Trap. I found this on the road near the house of Sir Thomas Acland, a few miles north of Exeter. I saw none of this in situ, though very commonly in the buildings in and about Exeter.

4. On quitting Exeter for Moreton, the road is extremely hilly, rising and descending over abrupt knolls almost all the way; these are principally formed of a soft decomposing rock, in thin strata, breaking in rhomboidal fragments, and very similar to the slaty. clay of Werner.

b,6,7.After passing Teign Bridge, this substance assumes a greater degree of consistence, and occurs in strata nearly verical, some of which are coarser in the grain than others. These were extremely difficult to break, and presented a close smooth fracture, approaching to conchoidal.

8. The Teign is the eastern boundary of Dartmoor, and within a few hundred yards of it, and inmediately beyond the stratified rock last mentioned, Granite occurs, containing very large cryatals of telspar, which continues to within a short distance of Tavisiock, situated on the Tavy, which bounds Dartmoor on the west side.

Here, as on the ba:ks of the Teign, the Killas rests upon the Granite. At Wheal Friendship, a mine at that time uncier the management of $\mathrm{Mr}$. John Taylor, (10 whose intelligence I am deeply indebted for a great share of the information I obtained in the comntry,) I selected the following specimens, as illustrative of the Cornish terms, which certainly afford the best explanation that can be given, of a langnage entirely peculiar.

9. Killas, by comparison with the Grauwacke Slate of Freyberg. I find this to be quite as similar as any 


\section{Remarks on the Transition Rocks of Werner.}

two specimens from the same quarry could be expected to be.

10. Elvan, as pointed out at Wheal Friendship. This 1 took for cuarse-grained Grauwacke; it was very difficult to break, and a very small proportion of it exposed to view. I could not, therefore, observe its connection with the surrounding rocks; hut, from more minute examination, I suspect it may belong to a bed of Greenstone.

11. Capel, a veinstone or Salland, composed of Quartz penetrated by Chlorite.

18. A Bunch of ore is here exhibited by a portion of Copper pyrites, in a vein of Quartz, which represents the lode. When found in this way in a mine, it is termed a Bunch of Metal.

13. A heave to the right, the Killas is here traversed in different directions by Quartz veins; that marked $A$ represents a Inde, intercepted and heaved to the right by $B$, a cross course. When the lode is cut in a very oblique direction, it is said to be caunted.

14. A Horse, when a lode is divided, and joins again, it is said to take horse, and the included mass in this specimen is called the Horse of Killas, \&c.

55. A Squat, wher the lode suddenly enlarges, it is called a Squat; and the metal it contains a Squat of Ore. -By means of this vocalulury, I very soun became familiar with many of the commonest mining terms in the country.

In order to form a junction between the Tavistock Canal and the Tamer, it becamre necessary to drive a tunnel, for a mile and a half, through a hill called Morwel Down, which promises to be a source of interest to the geologist. In forming this tunnel, several powerful veins of clay porphyry have been penetrated, the substance of which is in some places

Wns. much disintegrated, in others firm and compact; 16-19. veins supposed to correspond have since been observed on the surface.

30. In the tunnel, the Clay Porphyry alternates several times with the Killas, which is here of a light-gray colour, and a soft friable texture.

In the course of this undertaking, two workable metallic veins have been intersected : no traces of either had been found on the summit of the hill, although diligently examined.

21. Passing the Tamer, we enter Cornwall, and at Gunnis- 
lake is a mine of Copper in Granite; and a little beyond, at Drakewalls, there is another of $T w$ in No. Killas.

29. Tin-vein in Granite, from Carclaze, near St. Austle.

23. Killas found on the roar from Si. Austle to Carclaze; this I consiler a very perfect specimen of Grauwacke.

24. Mass of white Quartz, of which the roads are formed. 25. Mixlure of crystallized Quartz and Wolfram, covered with a coating of Bitumen, found in Poldice mine near Redruth, at the depth of 106 fathoms, in Granite.

26. Arsenical Pyrites, mixed with acicular, dark, greenishgray crystals, supposed to be actinelite, from Blaney's Shaft, a branch of Wheal Unity.

27. Granite, Cairn Brae.

28. From a vein which traverses the north-east side of Cairn Brae: on the spot it appeared to me to be Clay-Porpbry; in hand specimens it resembles fine. grained Granite.

29. Vein-stone of Quartz, impregnated with red Oxide of Iron, and containing white Steatite, from Tincroft.

30. From the high-road near Tincroft. This is a very tough rock, and very fine-grained: it appears to be a variety of Greenstome similar to Nis. 10.

31. Killas, marked with dark-coloured spots, from the side of the road to Cambourn, a little westward of the last.

82. Killas of a light-gray colour, from St. Anns.

33. From Beacon Hill, a conglomerate formed of the debris of Granite, very similar to some varieties of, Sandstone.

34,35. Granite from the Land's End.

36,37. Hornblend-rock from Botallock, a curious, little, but valuable mine, on the north side of the peninsula, near the extronity.

38. Cockle, massire Tourmaline, from the same place. 39-41.Specimens from the junction of the Granite and Killas, at St. Michael's Mount.

42,43. From the sbore near Penzance: these I consider to be Killas of a very tough and compact variety, they are found very near Granite, or some similar rock, which presented somcthing so peculiar in the aspect, that I cannot help recommending it to the attention of geologists. 
No.

-46.Serpentines from the Lizard.

47. Hornblend-rock, which forms the basis on which the light-houses of the Lizard stand.

48. Clay-porphyry, near Trewithin.

49. Granite, with a vein of 'Tin, St. Stephen's.

50. Conglomerate of Quartz and grauular Talc, from the same place.

51,52.Phosphate of Lime and crystallized Talc, in Granular Talc, from Stoney Gwins.

53. Killas from a quarry between Bodmin and the racecourse of that town. This substance is very soit, but well adapted for building, from the peculiar facility with which it is quarried; the stratification being horizontal, and the cross rens perpendicular, and so regular, the quarry presents a very symmetrical appearance.

54,55.Granite. coarse-grained, near Bndmin.

56. Fine-grained Killas, near Launcestown.

57. About seven miles from Lanncestown, on the road to Oakhampton, I found a quarry containing schistose and amorphous Killas interstratified, the last of which 1 belicve to be as perfect Grauwacke as any in the district of Lammermuir.

58. Greenstone, Hatherleigh.

59. Variety of Trap from Cleave.

60,61 . Killas from Ilfracombe, alluded to in page 22 .

Specimens quoted, lut not from the same Contutry.

62,63. Fine-grained Grauwacke, from Peeblesshire, in all respects similar to the Killas of Cornwall. Note, p. 23.

64,65. Shells in Killas, from Coniston. Note, p. 93.

66,67. Same from Fermoy, county of Cork, p. 93.

68,69. Gneiss from Coul, p. 96.

70. Transition Limestone from Rae Quarry, containing shells, p. is. 